\title{
George Stewart, Jr.: A Bibliography
}

George Stewart, Jr.'s bibliography indicates the extent of his work for Canadian literature, and his literary interests as a man of letters. In addition to his published works, the bibliography contains a list of his lectures, the journals he published, and the newspapers with which he was associated. Within each section items are organized chronologically. Letters found to date have been included, but there are many more to be discovered. Eulogies, minor notices, and reviews of Stewart's works have been omitted.

All the items in the bibliography have been verified. I am indebted for assistance in its preparation to the librarians and archivists of the Public Archives of Canada; the Archives of Ontario; the Metropolitan Toronto Reference Library; the Thomas Fisher Rare Book Library, University of Toronto; the Library of the Quebec National Assembly; the Literary and Historical Society of Quebec Library; the Harriet Irving Library, University of New Brunswick; the Ralph Pickard Bell Library, Mount Allison; and the New Brunswick Museum in Saint John. I would like particularly to thank Mrs. Apollonia Steele and the staff of Special Collections and InterLibrary Loans in the MacKimmie Library, University of Calgary.

Books and Monographs

The Story of the Great Fire in St. John, N.B., June 20, 1877. Toronto:

Belford, I877. 272 p. Dedication: 'To Gilbert Murdoch, Esq., C.E., a personal friend of the author and a gentleman who possesses the esteem of all the wide circle to whom he is known.'

Evenings in the Library: Bits of Gossip about Books and Those Who

Write Them. Saint John: R.A.H. Morrow, I878. 254 p. Dedication: 'To

Oliver Wendell Holmes, "The Autocrat of the Breakfast-Table," I dedicate this volume.' [Essays on Emerson, Lowell, Holmes, Carlyle, Longfellow, Whittier, Bryant, Howells, and Aldrich.]

Canada under the Administration of the Earl of Dufferin. Toronto:

Rose-Belford, I 878. 696 p. Dedication: 'To Francis Parkman of Boston, Mass., this volume is affectionately inscribed by the author.'

Lecture on Alcott. Quebec: Morning Chronicle, I880. 27 p. 
An Account of the Public Dinner to H.E. the Count of Premio-Real, Dec. 28, 1880. Quebec: Morning Chronicle, I88 I. I20 p.

Thomas Carlyle. Quebec: Morning Chronicle, I88I. 26 p. Dedication: 'To my wife, whose appreciation of the writings of Thomas Carlyle is not less hearty than my own, and at whose suggestion this lecture was prepared.'

Thoreau, the Hermit of Walden. Quebec: Morning Chronicle, I882. 30 p. Dedication: 'To the Hon. Judge Routhier, this paper is inscribed with the heartiest respect of the author.'

The Genius and Life-Work of Longfellow. Quebec: Morning Chronicle, I883. 26 p. Dedication: 'To my friend Chas. G.D. Roberts, M.A., the author of Orion, these pages are affectionately inscribed.'

Essays from Reviews. Quebec: Dawson, I 892. I7 I p. Dedication: 'To John George Bourinot, C.M.G., LL.D., D.C.L., President of the Royal Society of Canada, in remembrance of a long, unbroken friendship, I dedicate this book.' [Essays on Longfellow, Lowell, Holmes, and Whittier.]

Essays from Reviews. Second Series. Quebec: Dawson, I893. I59 p.

Dedication: 'To W. Harry Venning, Farmingdale, King's Co., N.B., my old and unvarying friend, I dedicate this book.' [Essays on Tennyson, Emerson, Adirondack Murray; and 'The History of a Magazine.']

Articles

'Introductory.' Stewart's Quarterly I (I867): I-2.

'Alexander Smith.' Stewart's Quarterly I (I 867): 38-39. [Unsigned]

'Solitude.' Stewart's Quarterly I (1867): 6I-62. [Unsigned]

'Holiday Thoughts.' Stewarts Quarterly I (I 868): I 25-27. [Unsigned]

'Mark Twain, the Humorist.' Stewart's Quarterly 2 (1 868): 47-50.

'Thomas D'Arcy McGee.' Stewart's Quarterly 2 (I 868): 67-78.

'Halloween.' Stewart's Quarterly 2 (I868): I77-8I.

'The Decline of the Legitimate Drama.' Stewart's Quarterly 3 (I 869): 305-8.

'Canadian Literature.' Stewart's Quarterly 3 (1 870): 403-7.

'Who is Enylla Allyne?' Stewart's Quarterly 4 (I870): I-6.

'Mr. E.L. Davenport as Sir Giles Overreach.' Stewart's Quarterly 4 (1870): 98-IO2.

'Alexandre Davy Dumas.' Stewart's Quarterly 4 (I 87 I): 386-94.

'The Dialect Poets: Bret Harte and John Hay.' Stewart's Quarterly 5 (I 87 I): 20-30.

'Mental Photographs.' Stewart's Quarterly 5 (I87 I): 5 I-54.

'Valedictory.' Stewart's Quarterly 5 (I872): 337-4I.

Introduction. Thistledown. By A.R. Garvie. Toronto: Hunter, Rose, I 874. iii-v. 
'A Defence of Charles Reade.' Watchman (Saint John) 22 Apr. I 876.

('From the pen of one of our youngest and most gifted literateurs [sic].') [Unsigned]

'Ballads of the Scaffold.' Canadian Monthly July I876: 32-35.

'Evenings in the Library: Carlyle.' Belford's Monthly Magazine Dec. I 876: $30-36$.

'Evenings in the Library: Emerson.' Belford's Monthly Magazine Jan. I877: 222-34.

'Evenings in the Library: Holmes.' Belford's Monthly Magazine Feb. I 877: 37 I-80.

'Evenings in the Library: Lowell.' Belford's Monthly Magazine Apr. I877: 65 I-59.

'Evenings in the Library: Longfellow.' Belford's Monthly Magazine June I 877: 48-64.

'Evenings in the Library: Whittier.' Belford's Monthly Magazine Oct. I 877: 696-7Io.

'Evenings in the Library: Bryant.' Belford's Monthly Magazine Nov. I877: 806-2I.

'Hanlan Defeats Plaisted.' Saint John Daily News I 8 May I 878.

'William Cullen Bryant.' Toronto Daily Mail I 3 June I 878.

'Geo. Stewart, Ir., and The Home Cook Book.' George Stewart Scrap Books 29 (r878): 6r. [Source unknown]

'A Minor Poet.' Potter's American Monthly (Philadelphia) Sept. I879: 210-I6.

'Salute to Louis Fréchette: A Toast to English Literature.' Quebec Morning Chronicle I 8 Nov. I880. Reprinted in Saint John Daily News 23 Nov. I880.

'The Death of George Eliot.' Quebec Morning Chronicle 25 Dec. I88o. [Unsigned]

'Professeur James DeMille.' 'Scrap-Book' contenant divers souvenirs personnels du Canada. Quebec: C. Darveau, I880. I75-92.

'The Beggar's Opera-tion.' 'Scrap-Book' contenant divers souvenirs personnels du Canada. Quebec: C. Darveau, I880. 207-I4.

'Sir Samuel Leonard Tilley.' The Canadian Portrait Gallery. Ed. John Charles Dent. 4 vols. Toronto: John B. Magurn, I880-8I. I: 54-8.

'The Hon. Adams George Archibald.' The Canadian Portrait Gallery. Ed. John Charles Dent. 4 vols. Toronto: John B. Magurn, I880-8I. I: 86-90.

'The Hon. Toussaint A.R. Laflamme.' The Canadian Portrait Gallery. Ed. John Charles Dent. 4 vols. Toronto: John B. Magurn, I88o-8I. I: 9 I-93.

'The Hon. Réné Edouard Carron.' The Canadian Portrait Gallery. Ed. John Charles Dent. 4 vols. Toronto: John B. Magurn, I880-8I. I: II6-I7. 
'The Hon. Edward Barron Chandler.' The Canadian Portrait Gallery. Ed. John Charles Dent. 4 vols. Toronto: John B. Magurn, I880-8I. I: I I 8-i 9 .

'The Hon. John Campbell Allen.' The Canadian Portrait Gallery. Ed. John Charles Dent. 4 vols. Toronto: John B. Magurn, I880-8I. I: I 85-86.

'The Most Rev. John Medley, D.D.' The Canadian Portrait Gallery. Ed. John Charles Dent. 4 vols. Toronto: John B. Magurn, I880-8I. 2: I-2. 'The Hon. Charles E.B. De Boucherville.' The Canadian Portrait Gallery.

Ed. John Charles Dent. 4 vols. Toronto: John B. Magurn, I880-8I. 3: 44. 'The Hon. Henri Gustave Joly.' The Canadian Portrait Gallery. Ed. John Charles Dent. 4 vols. Toronto: John B. Magurn, I880-8I. 3: 56-57.

'The Hon. John Joseph Caldwell Abbott.' The Canadian Portrait Gallery. Ed. John Charles Dent. 4 vols. Toronto: John B. Magurn, I880-8I. 3: 229-30.

'His Grace F.X. de Laval-Montmorency.' The Canadian Portrait Gallery. Ed. John Charles Dent. 4 vols. Toronto: John B. Magurn, I880-8I. 3: 233-35.

'The Hon. Sir William Young.' The Canadian Portrait Gallery. Ed. John Charles Dent. 4 vols. Toronto: John B. Magurn, I880-8I. 4: 43-47.

'The Hon. Timothy Warren Anglin.' The Canadian Portrait Gallery. Ed. John Charles Dent. 4 vols. Toronto: John B. Magurn, I880-8I. 4: I95-97.

'Longfellow in Canada.' Literary World (Boston) Feb. I88 I: 83-84. 'A Relic of a Fatal New Year's Eve.' Toronto Daily Mail 2 Dec. I883. Reprinted as 'Gen. Richard Montgomery.' New Age (Augusta, Me.) I I Jan. I 884 .

'Matthew Arnold.' Quebec Morning Chronicle I8 Feb. I884. [Unsigned] 'Materials for History.' The Week 29 May I884: 406-7.

'French-Canadian Poets and Novelists.' The Week 2 I Aug. I884: 599-660. 'New Brunswick.' Encyclopaedia Britannica. 9th ed. I 884. 7: 373-75.

'Nova Scotia.' Encyclopaedia Britannica. 9th ed. I884. 7: 60I-3.

'Frontenac and His Times.' French Explorations and Settlements in North America and Those of the Portuguese, Dutch, and Swedes. Vol. 4 of The Narrative and Critical History of America. Ed. Justin Winsor. 8 vols. New York: Houghton, I 884. 4: 317-68.

'Prof. Goldwyn Smith.' Quebec Morning Chronicle 25 July I 885. [Unsigned]

'Archdeacon Farrar.' Quebec Morning Chronicle I4 Sept. I885. [Unsigned]

'Prince Edward Island.' Encyclopaedia Britannica. 9th ed. I885. I9: 739-4I. 
Ior Fullerton: George Stewart, Jr.

'The Life and Times of Longfellow.' Scottish Review (London) July I 886: IOI-I 26. Reprinted in Essays from Reviews. Quebec: Dawson, I892. 9-68.

'Mr. Stewart's Report on Historical Studies in Canada.' Papers of the American Historical Society 2 (r 886): 86-89.

'Quebec.' Encyclopaedia Britannica. 9th ed. I886. 20: 165-68.

'Quebec City.' Encyclopaedia Britannica. 9th ed. I886. 20: I68-69.

'Letters in Canada.' The Week I6 June I887: 46I-62. Reprinted in The Search for English-Canadian Literature. Ed. Carl Ballstadt. Toronto: University of Toronto Press, 1975. 163-70.

'Canada in Fiction.' The Week 6 Oct. I887: 719-20.

'Mr. Stewart's Notes on the Present Condition of Historical Studies in Canada.' Papers of the American Historical Society 3 (I887-88): 2 I3-I5. 'Some Recent French-Canadian Books.' The Week I Mar. I888: 2 I6-17.

'Emerson the Thinker.' Scottish Review (London) Apr. I 888: 288-307. Reprinted in Essays from Reviews. Second Series. Quebec: Dawson, I893 - 43-92. Reprinted in Living Age (Boston) June I 888: 77 I-80.

'The Fisheries Treaty: A Canadian View.' Magazine of American History (New York) May I 888: 4I 6-23.

'A New Canadian Poet.' The Week I I Oct. I888: 734-45.

'Prominent Canadians: Louis Honoré Fréchette, LL.D., Poet and Journalist.' The Week i7 Nov. I888: 822-23.

'Macdonald, Sir John A.' Appleton's Cyclopaedia of American Biography. Ed. James Grant Wilson and John Fiske. 6 vols. New York: Appleton, I 888. Reprinted Detroit: Gale Research, I968. 4: I02-4.

'Ussher, Brandram Boileau.' Appleton's Cyclopaedia of American Biography. Ed. James Grant Wilson and John Fiske. 6 vols. New York: Appleton, I888. Reprinted Detroit: Gale Research, I968. 6: 2 I9.

'Young, Sir Charles.' Appleton's Cyclopaedia of American Biography. Ed. James Grant Wilson and John Fiske. New York: Appleton, I 888.

Reprinted Detroit: Gale Research, I968. 6: 647-48.

'Elizabeth Stuart Phelps and Her First Successful Book.' The Week I Mar. I 889: 198.

'Brief Notes on the Present Condition of Historical Studies in Canada.' Papers of the American Historical Society 4 (I 889): 107-9.

'Literature in French Canada.' New England Magazine (Boston) Sept. I 890: I 6-20.

'Brief Notes on the Present Condition of Historical Studies in Canada.' Papers of the American Historical Society 5 (I890): 7 I-74.

'Adirondack Murray.' Belford's Monthly (New York) Mar. I891: n.p. Reprinted in Essays from Reviews. Second Series. Quebec: Dawson, I893. 93-I 22. 
'Oliver Wendell Holmes.' Arena (Boston) July I89I: I29-4I. Reprinted in Essays from Reviews. Quebec: Dawson, I892. I I9-38.

'James Russell Lowell.' Arena (Boston) Oct. I89I: 513-29. Reprinted in Essays from Reviews. Quebec: Dawson, I 892. 69-107.

'Whittier, the New England Poet.' Arena (Boston) Dec. I891: 36-49.

Reprinted as 'John Greenleaf Whittier' in Essays from Reviews.

Quebec: Dawson, I892. I39-7I.

'Fiction in the Court Room.' The Week I I Mar. I892: 229-30.

'John Gilmary Shea.' Dominion Illustrated Monthly May I892: 203-6.

'The History of a Magazine.' Dominion Illustrated Monthly Aug. 1892: 400-8. Reprinted in Essays from Reviews. Second Series. Quebec: Dawson, I893. I23-59.

'The Late Sir Daniel Wilson, LL.D.' Dominion Illustrated Monthly Nov. I892: 587-90.

'Alfred, Lord Tennyson.' Cosmoplitan (New York) Dec. I 892: I69-78. Reprinted in Essays from Reviews. Second Series. Quebec: Dawson, I 893. 9-4I.

'Sir Leonard Tilley.' Men of the Day: A Canadian Portrait Gallery. Series

2 I. Ed. Louis-H. Taché. Montreal: Paper Mills, I892. I6I-65.

'The Canadian Question.' North American Review (Boston) Mar. I893: 382-84.

'Foreign Nations at the World's Fair: Canada.' North American Review (Boston) Mar. I 893: 6I3-I7.

'John George Bourinot.' Men of the Day: A Canadian Portrait Gallery. Series 26. Ed. Louis-H. Taché. Montreal: Paper Mills, I893. 20I-7. 'Andrew George Blair.' Men of the Day: A Canadian Portrait Gallery. Series 27. Ed. Louis-H. Taché. Montreal: Paper Mills, I893. 209-I 2. 'Sir Joseph Hickson.' Men of the Day: A Canadian Portrait Gallery.

Series 29. Ed. Louis-H. Taché. Montreal: Paper Mills, I893. 233-36.

'Views of Canadian Literature.' The Week 30 Mar. I894: 4I5-I6.

'Alcott, the Concord Mystic.' The Week 20 July i 894: 798-80o.

'Restless French Canada.' North American Review (Boston) Sept. I 894: 379-82.

'Thomas Bailey Aldrich.' The Week 5 Oct. I894: 1064-67.

'Henry David Thoreau.' Canadian Magazine Dec. I894: Ior-69.

'Recollections of Oliver Wendell Holmes.' Metropolitan (New York) Dec. I 894 .

'Lewis James Seargeant.' Men of the Day: A Canadian Portrait Gallery. Series 32. Ed. Louis-H. Taché. Montreal: Paper Mills, I894. 249-53. 'Some Unpublished Letters of the Earl of Lytton.' Canadian Magazine Feb. I895: 297-301. 
'Wanted, a New Diet.' Atlantic Monthly (Boston) June I895. Excerpt Montreal Gazette 8 June I 895 . Excerpt Literary Digest (New York) 8 June I895.

'An Historic Ship.' Saturday Night 3 I Aug. I 895. Reprinted in Quebec Morning Chronicle 26 Oct. 1895.

'Count Frontenac in New France.' Cosmopolitan (New York) Aug. I 896: 427-3I.

'Significance of the Canadian Elections.' Forum (New York) Aug. I 896: 753-60.

'The Premiers of Quebec since I 867.' Canadian Magazine Feb. I897: 289-98.

'Side Lights on Old Times.' Massey's Magazine Feb. I897: 95-98.

'The Catholic Question in Canada: The Index Expurgatorius in Quebec.' Arena (Boston) Apr. I897: 747-5 I.

'The First Canadian Cardinal.' Massey's Magazine Apr. I897: 23 1-37.

'General Montgomery's Invasion of Canada.' Self-Culture (Akron) May I 897: 205-7.

'The "Foil" of Historic Story-Telling.' Self-Culture (Akron) July I 897: 327-29.

'The Festival of St. Jean Baptiste.' Self-Culture (Akron) Nov. I897: I4446.

'Civic Address to the Queen.' Newspaper reprint of an illuminated and hand-printed address sent to Queen Victoria on her sixtieth anniversary by the City of Quebec, 1897. George Stewart Scrap Book 4I: 43. [Source unknown]

'An Early New Brunswick Magazine.' New Brunswick Magazine Aug. I 898: 79-8I.

'A New Year Ball: Gay Doings in Quebec a Hundred Years Ago.' Buffalo Express 2 Jan. I899. [Unsigned]

'Francis Parkman and His Works.' Canadian Magazine Aug. I 899: 36268. Reprinted as 'The Work of Francis Parkman.' New England Magazine (Boston) Aug. I899: 704-I I.

'Quebec.' New England Magazine (Boston) Sept. I 899: 3 I-5 I.

'Literary Reminiscences.' Canadian Magazine June I901: I63-66.

'The Archbishop of Quebec.' Canadian Magazine Nov. I90r: I6-I8.

'Bacchus in Fiction.' Crampton's Magazine (London) Mar. I902: 323-29.

'When Laurier Was Defeated.' Canadian Magazine July I902: 238-39.

'An Aquatic Reminiscence.' Canadian Magazine Jan. I904: 253-55.

'The Flag of Champlain and Its History.' Acadiensis 4 (I904): 22 I-25.

'Popular Songs of Old Canada.' Monthly Review (London) Apr. I905: 6475. Reprinted in Living Age (Boston) July I905: 162-67. 


\section{Reviews}

'The Royal Memoir.' Review of The Early Years of His Royal Highness the Prince Consort, by Hon. C. Gray. Stewart's Quarterly I (r 867): I 7 -I9. [Unsigned]

Dreamland and Other Poems, by Charles Mair. Stewart's Quarterly 2 (I 869): 247-50.

Political Notes and Observations, by George E. Fenety. Stewart's Quarterly 2 (1 869): 250-52.

Flowers of the Year and Other Poems, by Letitia F. Simson. Stewart's Quarterly 2 (I 869): 252-54.

Lectures, Literary and Biographical, by Rev. Moses Harvey. Stewart's Quarterly 2 (I869): 254-55.

Songs of a Wanderer, by Carroll Ryan. Stewart's Quarterly 3 (r869): 215$2 \mathrm{I}$.

Aberdeen and Its Folk, by Lewis Smith. Stewart's Quarterly 3 (I 869): 22I-22.

'Charles Sangster and His Poetry.' Review of The St. Lawrence and the Saquenay, and Other Poems, and Hesperus and Other Poems, by Charles Sangster. Stewart's Quarterly 3 (I869): 334-4I.

The Discovery of the Great West, by Francis Parkman. Stewart's Quarterly 3 (I870): 45 I-53.

Sybaris and Other Homes, by E.E. Hale. Stewart's Quarterly 3 (1870): 453-55.

The Story of a Bad Boy, by Thomas Bailey Aldrich. Stewart's Quarterly 3 (I870): 456.

'A Canadian History.' Review of A History of Canada for the Use of the Schools, by Henry H. Miles. Stewart's Quarterly 4 (I 870): 220-2 I.

The Wreck of the White Bear, by Mrs. Ellen Ross. Stewart's Quarterly 4 (I 870): 327-30.

The Prophecy of Merlin and Other Poems, by John Reade. Stewart's Quarterly 4 (I87I): 43 I-38.

Ten Great Religions, by James Freeman Clarke. Stewart's Quarterly 5 (I87I): 2I4-2I.

'A New Book of Scottish Poetry.' Review of Poems and Songs, by William Murdoch. Stewart's Quarterly 5 (I872): 382-91.

'Some Love Idylls.' Review of My Witness, by William Winter. Stewart's Quarterly 5 (1872): 4I9-24.

Tom Bailey: Or the Adventures of a Bad Boy, by Thomas Bailey Aldrich. George Stewart Scrap Books 29 (I878): I6. [Source unknown] Lady Dufferin's Songs and Poems, edited by the Earl of Dufferin. Independent (New York) 29 Nov. I 894. Reprinted in Quebec Morning Chronicle ro Dec. I894. Excerpt in L'Electeur (Quebec) I 5 Dec. I 894. 
I05 Fullerton: George Stewart, Jr.

The Story of Canada, by J.G. Bourinot. Review of Historical Publications Relating to Canada. Ed. G.M. Wrong. 22 vols. Toronto: William Briggs, I897. I: I9-2 I.

A History of Newfoundland from the English, Colonial, and Foreign Records, by D.W. Prowse. Review of Historical Publications Relating to Canada. Ed. G.M. Wrong. 22 vols. Toronto: William Briggs, I897. I: 2I-24.

L'Ouest Canadien, sa découverte par le Sieur de la Vérendrye, son exploitation par les companies de traiteurs jusqu'à l'anneé 1822, by L'Abbé G. Dugas. Review of Historical Publications Relating to Canada. Ed. G.M. Wrong. 22 vols. Toronto: William Briggs, I897. I: 47-50.

The Journal of Captain William Pote, Jr., during His Captivity in the French and Indian Wars, from May, 1745 to Aug. 1747. Review of Historical Publications Relating to Canada. Ed. G.M. Wrong. 22 vols. Toronto: William Briggs, I897. I: 50-54. Reprinted in American Historical Review 2 (1 896-97): I 57-59.

The Life and Times of Sir Leonard Tilley, by James Hannay. Review of Historical Publications Relating to Canada. Ed. G.M. Wrong. 22 vols. Toronto: William Briggs, I897. I: 87-89.

Le Saquenay et le bassin du Lac St. Jean, by Arthur Buies. Review of Historical Publications Relating to Canada. Ed. G.M. Wrong. 22 vols. Toronto: William Briggs, I 897. I: I37-40.

A Compendious History of the Northern Part of the Province of New Brunswick, by Robert Cooney. Review of Historical Publications Relating to Canada. Ed. G.M. Wrong and H.H. Langton. 22 vols. Toronto: University of Toronto Press, I898. 2: I09-I I.

Québec et Lévis à l'aurore du $\mathrm{xx}^{\mathrm{e}}$ siècle, by A.B. Routhier. Review of Historical Publications Relating to Canada. Ed. G.M. Wrong and H.H. Langton. 22 vols. Toronto: University of Toronto Press, I9OI. 5: I03-4.

\section{Short Stories}

'Women's Rights,' by Hannibal Hatblock [possible pseud.]. Stewart's Quarterly I (I 867): 30-32.

'Storm-Stayed, and the Story Which Grew out of It.' Stewart's Quarterly 4 (I870): 306-I6.

'Minktan Pellidee's Serenade: A Story of a Wronged Heart.' Stewart's Quarterly 5 (I87I): 44-5 I.

'How Five Little Midgets Spent Christmas Eve.' Belford's Monthly Magazine Jan. I 878: 238-44.

'A Montmorency Adventure.' Canadian Magazine July ı 906: 259-65. 


\section{Lectures}

'Emerson, the Thinker.' Mechanics Institute, Saint John, N.B., I I Feb. I878. Saint John Daily News I2 Feb. I 878.

'Emerson, the Thinker.' Literary and Historical Society of Quebec, 9 Jan. I879. Transactions of the Literary and Historical Society of Quebec. Sessions of I 877-78-79: I I 5-43.

'Alcott, the Concord Mystic.' Literary and Historical Society of Quebec, 29 Jan. I880. Transactions of the Literary and Historical Society of Quebec. Sessions of I879-80: 87-I I I. Reprinted as Lecture on Alcott. Quebec: Morning Chronicle, I880.

'Thomas Carlyle.' Literary and Historical Society of Quebec, 25 Mar. I $88 \mathrm{I}$. Transactions of the Literary and Historical Society of Quebec. Sessions of I880-8I: 95-I I7. Reprint Quebec: Morning Chronicle, I $88 \mathrm{I}$.

'Thoreau, the Hermit of Walden.' Literary and Historical Society of Quebec, 7 Mar. I882. Transactions of the Literary and Historical Society of Quebec. Sessions of I88I-82: I2 I-50. Reprint Quebec: Morning Chronicle, I 882.

'The Genius and Life-Work of Longfellow.' Literary and Historical Society of Quebec, 7 Mar. I 883. Transactions of the Literary and Historical Society of Quebec. Sessions of I883-84: 69-94. Reprint Quebec: Morning Chronicle, I883.

'New France from the First Administration of Frontenac to the Massacre of Lachine.' Paper read before the Literary and Historical Society of Quebec, I I Mar. I 884. See 'List of Unpublished Papers.' Transactions of the Literary and Historical Society of Quebec. Sessions of I889-9I: xlviii. Verbatim report Quebec Morning Chronicle I 2 Mar. I884.

'Sources of Early Canadian History.' Royal Society of Canada, 28 May, I 885. Transactions and Proceedings of the Royal Society of Canada 3 (I885): Section 2, 39-44.

'The Administration of Denonville and the Second Term of Count Frontenac.' Paper read before the Literary and Historical Society of Quebec, I9 Nov. I 885. See 'List of Unpublished Papers.' Transactions of the Literary and Historical Society of Quebec. Sessions of I889-9I: xlviii. Verbatim report Quebec Morning Chronicle 20 Nov. I 885.

'Canadian Literature.' King's College Convocation, Windsor, N.s., 24 June I 886. Quebec Morning Chronicle 25 June I886. Excerpt King's College Record May-June I 886: 93-94.

'Whittier, the New England Poet.' Paper read before the Literary and Historical Society of Quebec, 7 Jan. I 887. See 'List of Unpublished Papers.' Transactions of the Literary and Historical Society of Quebec. Sessions of I889-9I: xlix. 
'Literature in Canada.' Canadian Club of New York, r887. Canadian Leaves: History, Art, Sciences, Literature, Commerce. A Series of New Papers Read before the Canadian Club of New York. Ed. G.M.

Fairchild, Jr. New York: Thompson, r887. 29-45.

'Oliver Wendell Holmes.' Paper read before the Literary and Historical Society of Quebec, 27 Jan. I891. See 'List of Unpublished Papers.'

Transactions of the Literary and Historical Society of Quebec.

Sessions of I889-9I: xlix.

Journals Published by Stewart

Stamp Collector's Monthly Gazette. Saint John: June I865-May I 867. Stewart's Quarterly. I-5 (Apr. I867-Jan. I872). Vols. I and 2 called Stewart's Literary Quarterly Magazine: Devoted to Light and Entertaining Literature. (Apr. I867-Jan. I869). Vol. 3 called Stewart's Quarterly Magazine. (Apr. I869-Jan. I870).

Newspapers and Journals Edited by Stewart

Saint John Daily News: city editor, I87 I-I 875.

Watchman (Saint John): book reviewer and drama critic, I875-I877.

Rose-Belford's Canadian Monthly: editor, I878-1879.

Quebec Morning Chronicle: editor-in-chief, I879-1 896.

Quebec Daily Mercury: editor and publisher, I898-I902.

Quebec Daily Mercury: editor, I902-1903.

Quebec Morning Chronicle: night editor, I903-I906.

\section{Unpublished Papers}

Archives of Ontario, Toronto, Ont. Mackenzie-Lindsey Collection. Three autograph letters from George Stewart, Jr. to Charles Lindsey.

Metropolitan Toronto Reference Library, Toronto, Ont. Baldwin Room. George Stewart Papers. Bound collection of eighty-five autograph letters to George Stewart, Jr.

Mount Allison University, Sackville, N.B. Ralph Pickard Bell Library. George Stewart Scrapbooks. Vols I-40. I87I-I902.

Public Archives of Canada. Fréchette Papers. MG 29, D 40. Microfilm. Reels CI 3987 to CI3989. Three autograph letters, one telegram, from George Stewart, Jr. to Louis Fréchette.

Public Archives of Canada. Grant Papers. MG 30. Microfilm. Reel cr 872. One autograph letter from George Stewart, Jr. to George Grant.

Public Archives of Canada. Laurier Papers. Mg 26, G. Microfilm. Reels C742, C749, C754, C770, C77I. Six autograph letters from George Stewart, Jr. to Sir Wilfred Laurier. Reel c790. Two typed letters to George Stewart, Jr. from Sir Wilfred Laurier. 
Public Archives of Canada. George Stewart Collection. MG 27, I I 25. Five autograph letters to George Stewart, Jr.: three from the Marquis of Lorne, one from Lord Stanley of Preston, and one from Sir James MacPherson LeMoine.

University of Toronto, Toronto, Ont. Thomas Fisher Rare Book Library. Henry Sproatt Collection. Two autograph letters to George Stewart, Jr. from John Charles Dent.

Carol W. Fullerton, Calgary, Alta. Two autograph letters to George Stewart, Jr. from Matthew Arnold.

Lois Rumsey, Edmonton, Alta. George Stewart Scrapbook. Vol. 4I. [Mrs. Rumsey is George Stewart, Jr.'s great-granddaughter.] 